\title{
Modul Relasi dan Fungsi Berbasis Kemampuan Komunikasi Matematis
}

\author{
Muhammad Sofyan Ats-Tsauri ${ }^{1}$, Yus Mochamad Cholily ${ }^{2 *}$, Rizal Dian \\ Azmi $^{3}$, Putri Ayu Kusgiarohmah ${ }^{4}$ \\ 1,2,3Pendidikan Matematika, Universitas Muhammadiyah Malang, Malang, Indonesia; \\ 1aan130398@gmail.com; ${ }^{2 *}$ yus@umm.ac.id; ${ }^{3}$ rizaldian@umm.ac.id; \\ ${ }^{4}$ Pendidikan Matematika Universitas Negeri Malang, Malang, Indonesia; \\ ${ }^{4}$ ayuputrikusgiarohmah@gmail.com ${ }^{4}$
}

Info Artikel: Dikirim: 1 Juli 2020; Direvisi: 18 September 2020; Diterima: 25 Februari 2021

Cara sitasi: Ats-Tsauri, M. S., Cholily, Y. M., Azmi, R. D., \& Kusgiarohmah, P. A. (2021). Modul Relasi dan Fungsi Berbasis Kemampuan Komunikasi Matematis. JNPM (Jurnal Nasional Pendidikan Matematika) 5(1), 109-124.

\begin{abstract}
Abstrak. Komunikasi menjadi alat bagi siswa untuk menyampaikan pemikirannya agar dapat dipahami oleh orang lain. Mengingat pentingnya kemampuan komunikasi matematis, guru bertugas untuk membantu siswa dalam mengembangkan kemampuan tersebut. Terdapat banyak cara yang bisa digunakan oleh guru, salah satunya penggunaan bahan ajar yang tepat guna. Penelitian ini membahas tentang pengembangan modul yang menekankan pada kemampuan komunikasi siswa agar bisa digunakan sebagai bahan ajar guru dalam membantu siswa. Penelitian dilakukan di Kelas VIII SMP Negeri di Batu dengan sampel penelitian sebanyak 23 siswa. Penelitian ini menggunakan pendekatan Mixmethod dengan model pengembangan ADDIE. Hasil dari validasi modul, uji keefektifan, uji normalitas, dan uji Wilcoxonmenyatakan bahwa terdapat peningkatan kemampuan komunikasi matematis tertulis siswa sebelum dan sesudah menggunakan bahan ajar modul dengan interpretasi "sedang". Hasil uji kepraktisan juga menyatakan bahwa modul ini praktis untuk digunakan.Berdasarkan pernyataan tersebut, dapat disimpulkan bahwa modul yang dikembangkan valid, efektif, dan praktis untuk digunakan sebagai bahan ajar guru dalam membantu siswa mengembangkan kemampuan komunikasi matematisnya.
\end{abstract}

Kata Kunci: Bahan Ajar, Komunikasi Matematis Tertulis, Modul, Relasi dan Fungsi.

Abstract. Communication becomes a tool for students to convey their thoughts so that others can understand them. Given the importance of mathematical communication skills, teachers are tasked with assisting students in developing these abilities. Many ways can be used by teachers, one of which is the use of appropriate teaching materials. This study discusses the development of modules that emphasize students' communication skills to be used as teaching materials for teachers in helping students. The research was conducted in Class VIII of SMP Negeri in Batu with a sample of 23 students. This study uses a mixed-method approach with the ADDIE development model. The results of module validation, effectiveness test, normality test, and Wilcoxon test stated that there was an increase in students' written mathematical communication skills before and after using module teaching materials with "moderate" interpretation. The results of the practicality test also indicate that this module is practical to use. Based on this statement, it can be concluded that the developed module is valid, effective, and practical to be used as teacher teaching material in helping students develop their mathematical communication skills. 
Keywords: Teaching Materials, Written Mathematical Communication, Modules, Relation and Functions.

\section{Pendahuluan}

Pembelajaran matematika pada tingkat SMP memiliki tujuan agar siswa dapat membangun konsep matematika, menjabarkan keterkaitan antar konsep satu dengan konsep lainnya, dan menerapkan konsep atau algoritma dengan baik, cermat, praktis dan tepat dalam penyelesaian suatu masalah matematika (Mawaddah \& Anisah, 2015). Komunikasi merupakan salah satu keterampilan yang dapat digunakan untuk merealisasikan tujuan pembelajaran tersebut.Komunikasi dalam matematika disebut dengan komunikasi matematis. Kemampuan komunikasi matematis memiliki arti tentangsuatu kemampuan siswa dalam menyampaikan materi yang diketahuinya melalui dialog yang terjadi di kelasdan didalam proses tersebut terjadi pengalihan pesan (Lanani, 2013). Dengan kata lain, komunikasi matematis adalah suatu proses interaksi dengan pemberian informasi antara komunikator dengan komunikan.

Kaya dan Aydin (2016) menyatakan bahwa komunikasi matematis menjadi alat yang penting bagi guru untuk melihat Mathematical Thinking siswa. Peningkatan kualitas pembelajaran dan pemahaman siswa dibidang matematika dapat ditingkatkan dengan mengembangkan komunikasi matematis (Rohid, Suryaman, \& Rusmawati, 2019). Terdapat dua jenis komunikasi matematika, yaitu komunikasi matematika tertulis dan komunikasi matematika lisan (Puspa, Riyadi, \& Subanti, 2019). Pada penelitian ini, komunikasi matematika yang akan diteliti adalah komunikasi tertulis siswa. Komunikasi tertulis menurut Asmana (2018) merupakan kemampuan siswa dalam menyampaikan ide matematikanya menggunakan gambar, simbol, kosakata, dan notasi beserta strukturnya secara tertulis. Komunikasi tertulis dipilih karena bahasa, simbol bilangan, informasi dan perhitungan yang menjadi alat komunikasi merupakan komponen penting dalam memecahkan masalah (Parrot \& Leong, 2018). Pemahaman siswa mengenai simbol-simbol matematika, ide, gagasan, konsep, rumus, dan penyelesaian masalah lebih mudah dipahami jika siswa mengomunikasikan kemampuannya secara tertulis.

Relasi dan fungsi menjadi salah satu materi pada pembelajaran matematika di Sekolah Menengah Pertama (SMP). Relasi dan fungsi merupakan materi yang tergolong sulit, perlu pemahaman yang lebih teliti untuk setiap subbabnya (Herawati, 2014). Siswa cenderung tidak memahami konsep sesungguhnya dari relasi dan fungsi, siswa hanya mengenal materi tetapi tidak mengetahui makna dari materi tersebut (Suhartati, 2016). Siswa dapat membangun konsep 
dengan proses peninjauan atau memikirkan sesuatu yang konkret terlebih dahulu. Siswa yang menguasai konsep ialah yang mampu mengerti, mengenali dan mengabstraksi sifat yang sama, dan mampu menggeneralisasi konsep tersebut. Proses penguasaan konsep matematika tersebut dilakukan melalui pengalaman, definisi atau pengamatan secara langsung yang bertahap (Lutvaidah, 2016).

Studi pendahuluan di SMP Negeri yang berada di Kota Batu menunjukkan bahwa siswa mengalami beberapa miskonsepsi dalam mempelajari sifat-sifat relasi dan fungsi. Terdapat beberapa siswa yang memahami ciri-ciri dari Relasi dan Fungsi tetapi kesulitan dalam mengaplikasikannya pada soal-soal yang diberikan. Terbukti ketika soal tipe A diberikan sebagai latihan di kelas yaitu disajikan suatu fungsi $2 x-3$, kemudian soal tersebut di ujikan dalam Ujian Sekolah dengan hanya merubah bilangannya saja menjadi $2 x-2$, siswa sudah merasa kebingungan dalam menjawab soal tersebut. Siswa hanya menuliskan soal, belum sampai pada langkah mensubstitusikan nilai $x$ ke dalam suatu fungsi yang diketahui. Ketikasiswa menuliskan penyelesaian soal, terdapat langkah yang terlewat atau dilompati. Siswa langsung menuliskan hasil akhir dari soal tersebut tanpa menuliskan proses penyelesaiannya. Hal tersebut menunjukkan siswa belum bisa menentukan strategi penyelesaian masalah berupa persamaan aljabar. Sehingga dari studi ini terlihat bahwa siswa kesulitan untuk mengkomunikasikan pemikirannya dalam bentuk tulisan dengan menggunakan aturan dan bahasa matematika yang sesuai.

Setelah dikaji lebih dalam, peneliti menemukan beberapa faktor yang mempengaruhi rendahnya komunikasi siswa. Metode pengajaran yang digunakan hanya berpusat pada guru, sehingga siswa menjadi pasif dan membuat suasana pembelajaran menjadi membosankan. Adapun faktor lain yang mempengaruhi adalah bahan ajar. Ketika proses pembelajaran berlangsung, guru hanya menggunakan buku paket Kurikulum 2013 dimana buku tersebut sulit untuk dipahami siswa.Buku paket kurikulum 2013 merupakan buku siswa yang disusun dan ditelaah oleh berbagai pihak dibawah naungan Kementerian Pendidikan dan Kebudayaan sebagai implementasi awal dari pemberlakuan kurikulum 2013. Semenjak buku paket ini digunakan, terdapat beberapa penelitian yang mengkaji tentang kelayakan buku tersebut hingga muncul buku paket kurikulum 2013 edisi revisi tahun 2019 sebagai hasil perbaikan dari buku sebelumnya.

Namun di SMP ini, guru masih menggunakan buku paket kurikulum 2013 dimana prosedur yang terdapat dalam buku paket tersebut belum 
menekankan pada peningkatan keterampilan komunikasi matematis siswa. Siswa juga jarang membaca buku paket yang diberikan oleh sekolah karena materi yang tercantum didalamnyakurang menarik. Rizkianto \& Santosa (2017) menambahkan, buku paket matematika 2013 masih memuat kesalahan konsep matematika, seperti pejelasan dalam menentukan gradien dari grafik fungsi. Hal tersebut mengakibatkan kemampuan komunikasi matematis tertulis siswa menjadi kurang, sehingga diperlukan bahan ajarselain buku paket untuk mendampingi belajar siswa yang lebih menekankan pada kemampuan komunikasi matematis (Ramdani, 2012).

Modul merupakan salah satu bahan ajar yang dapat membantu siswa belajar secara mandiri sehinga siswa tidak selalu bergantung pada guru maupun orang lain (Ramdani, Syamsuddin, \& Sirajuddin, 2019). Guru dituntut untuk bisa mengembangkan proses pembelajaran agar lebih variatif khususnya dalam pengembangan bahan ajar dan berperan sebagai fasilitator yang membantu siswa dalam memanfaatkan sumber belajar yang tersedia (Agustyarini \& Jailani, 2015). Hasil penelitian yang dilakukan Lestari \& Handayani (2018) menunjukkan, pengembangan bahan ajar modul matematika berbasis konsep matematika realistik membuat siswa lebih tertarik untuk mempelajari materi yang diajarkan karena materi yang disampaikan menggunakan kata-kata yang mudah dipahami serta isi dari materi tersebut bersifat komunikatif. Wahyuni, Yati, \& Fadila, (2020) sebelumnya telah mengembangkan modul pembelajaran matematika berbasis REACT untuk mengembangkan kemampuan komunikasi matematis siswa. Hasil penelitiannya menunjukkan bahwa modul tersebut memiliki pengaruh yang signifikan terhadap keterampilan komunikasi matematis siswa. Hasil uji kemampuan komunikasi matematis siwa dengan menggunakan modul tersebut memperoleh skor rata-rata 86,57 dengan kategori "sangat baik". Merujuk dari pemaparan hasil tersebut, penelitian ini dirancang untuk melanjutkan pengembangan modul di sekolah yang berbeda dan materi yang berbeda. Hal ini dikarenakan modul yang dikembangkan oleh Wahyuni, dkk hanya dapat diimplementasikan di MTs Nurul Huda Tekad Tanggamus.

Merujuk pada pemaparan tersebut, penelitian ini akan mengkaji pengembangan bahan ajar berupa modul. Tujuan dari penelitian ini untuk membantu guru dalam membuat bahan ajar yang bisa mempermudah siswa mempelajari materi dan memahami konsep Relasi dan Fungsi.

\section{Metode}

Penelitian ini menggunakan pendekatan kuantitatif dengan jenis penelitianResearch and Development (RnD). Modul yang dikembangkan 
diimplementasikan pada materi relasi dan fungsi pada siswa SMP kelas VIII di SMPN 3 Batu. Produk yang dihasilkan adalah bahan ajar berupa modul pada materi relasi dan fungsi.

Model penelitian ini merujuk pada model pengembangan Dick dan Carey (1978) yaitu ADDIE (Analysis, Design, Development, Implementation, dan Evaluation). Tahapan ADDIE yang digunakan dalam penelitian ini dijabarkan dalam Tabel 1.

Tabel 1. Tahapan ADDIE

\begin{tabular}{|c|c|}
\hline Tahapan & Keterangan \\
\hline Analysis & $\begin{array}{l}\text { analisis permasalahan siswa terkait kemampuan komunikasi matematis tertulis } \\
\text { siswa dalam pemahaman konsep materi relasi dan fungsi serta kebutuhan dari } \\
\text { bahan ajar modul yang akan dibuat }\end{array}$ \\
\hline Design & $\begin{array}{l}\text { Perancangan bahan ajar modul dan instrumen penelitian sesuai dengan kebutuhan } \\
\text { permasalahan yang ada }\end{array}$ \\
\hline Development & $\begin{array}{l}\text { Pengembangan produk yang sudah dirancang. Pada tahap ini peneliti akan } \\
\text { menghasilkan produk akhir berupa modul yang siap digunakan dan divalidasi } \\
\text { oleh validator yaitu dosen ahli dan guru. }\end{array}$ \\
\hline Implementation & $\begin{array}{l}\text { Setelah produk sudah siap digunakan dan divalidasi, modul diimplementasikan } \\
\text { kepada } 23 \text { siswa kelas VIII di salah satu SMP Negeri di Kota Batu dengan teknik } \\
\text { Accidental Random Sampling }\end{array}$ \\
\hline Evaluation & $\begin{array}{l}\text { Tahap ini merupakan tahap penilaian dari modul yang telah dibuat sudah valid, } \\
\text { efektif, dan praktis. }\end{array}$ \\
\hline
\end{tabular}

Teknik pengumpulan data yang digunakan adalah validasi ahli yang dilakukan oleh dosen ahli dan guru sebagai validator, penyebaran angket mengenai respon siswa terhadap modul yang digunakan (Mawaddah dan Maryanti, 2016), dan tes yang berupa pretest dan posttest. Teknik analisis kuantitatif digunakan untuk menganalisis data terkait uji kevalidan modul, tes, dan angket respon siswa. Uji kevalidan modul dilakukan menggunakan skala likert yang telah dimodifikasi menjadi empat kategori penilaian. Hasil uji kevalidan modul diukur menggunakan persentase validitas.

$$
\text { PersentaseValiditas }=\frac{\text { Jumlah skoryangdiperoleh }}{\text { Skortotal }} \times 100 \%
$$

Tabel 2. Skala Persentase Menurut (Arikunto, 2010)

\begin{tabular}{cl}
\hline Persentase Pencapaian & Interpretasi \\
\hline$p \geq 75 \%$ & Sangat Valid \\
$55 \% \leq p<75 \%$ & Valid \\
$40 \% \leq p<55 \%$ & Cukup Valid \\
$p<40 \%$ & Kurang Valid \\
\hline
\end{tabular}


Setelah dilakukan uji kevalidan modul, selanjutnya diteliti keefektifan dari modul melalui peningkatan kemampuan komunikasi matematis tertulis siswa. Peningkatan kemampuan komunikasi matematis diuji menggunakan uji paired sample t test (data normal) atau uji Wilcoxon (data tidak normal). Uji dilakukan menggunakan software SPSS. Adapaun hipotesis pada uji yang digunakan:

$\mathrm{H}_{0}=$ Tidak ada peningkatan kemampuan komunikasi matematis tertulis siswa sebelum dan sesudah menggunakan bahan ajar modul

$\mathrm{H}_{1}=$ Ada peningkatan kemampuan komunikasi matematis tertulis siswa sebelum dan sesudah menggunakan bahan ajar modul

Setelah diketahui apakah terdapat peningkatan atau tidak, data diuji menggunakan rumus gain ternomalisasi (N-Gain), untuk mengetahui interpretasi dari peningkatan data (Hake, 1999).

$$
N-\operatorname{Gain}(g)=\frac{\text { NilaiPosttest }- \text { NilaiPretest }}{\text { Nilaimaksimum }- \text { NilaiPretest }}
$$

Tabel 3. Klasifikasi Hasil Hitung Peningkatan

\begin{tabular}{cl}
\hline Nilai Gain & Interpretasi \\
\hline$g \geq 0.7$ & Tinggi \\
\hline $0.3 \leq g<0.7$ & Sedang \\
\hline $0<g<0.3$ & Rendah \\
\hline
\end{tabular}

Modul dikatakan efektif jika hasil hipotesis analisis uji paired sample t test atau uji Wilcoxon $\mathrm{H}_{1}$ diterima atau ada peningkatan kemampuan komunikasi matematis tertulis siwa dan termasuk dalam interpretasi "Sedang" atau "Tinggi" (Saddadi, 2019) dari klasifikasi N-Gain.

Kepraktisan modul dilihat dari data lembar angket respon siswa. Penilaian yang digunakan untuk uji kepraktisan bahan ajar modul adalah skala Ghuttman. Respon dianggap positif apabila persentase yang didapat lebih besar atau sama dengan 70 persen ( $\geq$ 70\%) (Kiswanto dan Amin, 2012).

$$
\text { Persentase }(\%)=\frac{\text { jumlah jawaban "ya" }}{\text { Skormaksimal }} \times 100 \%
$$

\section{Hasil dan Pembahasan}

Berikut ini penjabaran dari pengembangan bahan ajar modul menggunakan model pengembangan ADDIE. 


\section{Analysis}

Berikut ini cuplikan wawancara antara peneliti dengan salah satu siswa kelas VIII, dimana peneliti sebagai P dan siswa sebagai S.

\section{$P$ : Apa kesulitan kamu saat mengerjakan soal relasi dan fungsi? \\ $S$ : Saya kadang bingung membedakan mana yang relasi dan mana yang fungsi pak \\ $P$ : Ada lagi kesulitan yang lain? \\ $S$ : Saat mengerjakan soal, terkadang saya bingung gimana menuliskannya pak, tapi saya tahu jawabannya apa" \\ $P$ : Lalu apa yang kamu lakukan? \\ $S$ : Ya saya tulis soalnya aja, ataucuma tulis jawabannya saja.Terkadang apa yang saya ingat dari materinya saya tulis saja walaupun tidak tahu itu benar atau salah. Dan yang paling susah itu yang eliminasi dan substitusi pak \\ P : Jadi, kesulitan yang kamu alami itu mengenai kesulitan menuliskan apa yang kamu sudah belajar dari materinya. Dan juga ada beberapa konsep relasi dan fungsi yang masih belum kamu paham.}

Berdasarkan cuplikan tersebut, siswa kesulitan saat mengerjakan soal yang berkaitan dengan fungsi yang melibatkan operasi eliminasi dan substitusi, siswa juga belum bisa mengungkapkan atau menuliskan apa yang mereka pahami kedalam sebuah tulisan. Siswa kebingungan saat memahami materi yang termuat dalam buku paket Kurikulum 2013 karena bahasa yang digunakan belum komunikatif. Selain itu, siswa belum terbantu untuk mengembangkan kemampuan komunikasi matematis tertulisnya melalui buku tersebut. Hal itu sejalan dengan penelitian yang dilakukan oleh Yanti, Melati, \& Zanty (2019) yang menyatakan, jika dilihat dari segi kemampuan komunikasi matematis, siswa masih mengalami kesulitan mempelajari materi tentang relasi dan fungsi.

\section{Design}

Penyusunan modul disesuaikan dengan kurikulum yang berlaku yaitu Kurikulum 2013. Modul yang dirancang berisi materi yang menekankan pada kemampuan komunikasi tertulis siswa. Desain dari modul ini berisimateri yang dikaitkan dengan kehidupan sehari-hari dan juga gambar-gambar yang menarik agar siswa tidak jenuh dalam membaca dan mempelaiarinya. Adapun isi dari modul terdiri dari cover, mindmap (peta konsep), dan materi yang terdiri dari ilustrasi dalam kehidupan sehari-hari, materi, contoh soal, dan latihan soal.Selanjutnya setelah merancang modul, rancangan instrumen penelitian yang berupa lembar validasi, lembar angket, dan lembar soal tes juga dilakukan pada tahapan ini.

Lembar validasi digunakan untuk mengetahui kevalidan dari instrumen penelitian yang digunakandan akan divalidasi oleh dosen dan guru.Lembar 
angket digunakan untuk mendapatkan data terkait kepraktisan dari modul berdasarkan respon siswa terhadap bahan ajar modul. Lembar soal tes yang digunakan terdapat dua macam yaitu soal pretest dan posttest. Lembar soal pretest digunakan untuk mengetahui kemampuan awal siswa dalam mengukur peningkatan kemampuan komunikasi matematis tertulis siswa pada materi relasi dan fungsi. Lembar soal posttest digunakan untuk mengetahui peningkatan kemampuan komunikasi matematis tertulis siswa setelah uji coba bahan ajar modul. Peneliti menyusun sendiri lembar validasi dan lembar angket. Terdapat dua kisi-kisi dalam lembar validasi soal yaitu materi dan aspek isi media, sedangkan kisi-kisi lembar validasi modul yaitu tampilan, tulisan, bahasa, isi, penyajian materi, dan kemanfaatan modul, dan untuk kisi-kisi lembar validasi angket yaitu format isi, isi, kemenarikan, dan kemudahan. Kisi-kisi lembar angket terdiri dari desain modul, isi modul, dan kemanfaatan modul.

\section{Development}

Tahap development merupakan tahapan dalam proses pembuatan instrumen penelitian dan penyusunan bahan ajar berupa modul. Proses pembuatan modul diawali dengan pemilihan materi dari relasi dan fungsi yang disesuaikan dengan kompetensi dasar dan indikator pencapaian kompetensi pada kurikulum 2013. Materi yang dipilih adalah relasi, fungsi, dan korespondensi satu-satu. Pengembangan modul didesain untuk meningkatkan kemampuan komunikasi matematis tertulis siswa. Hal itu sesuai dengan penelitian yang dilakukan oleh Wahyuni, Yati, \& Fadila, (2020) bahwa pembelajaran dengan menggunakan modul dapat membantu siswa meningkatkan kemampuan komunikasi matematisnya. Pengembangan dan desain modul dilakukan dengan menyesuaikan materi dan indikatorindikator komunikasi matematis tertulis. 


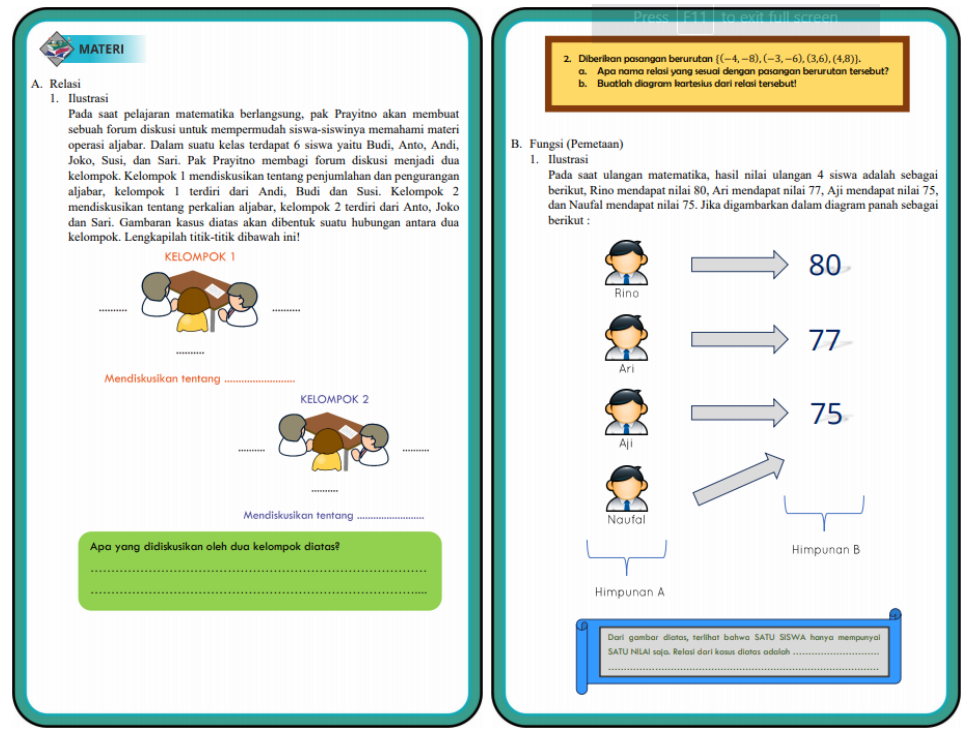

Gambar 1. Ilustrasi Modul

Sebelum memasuki materi relasi dan fungsi, terdapat sebuah ilustrasi berupa kasus dalam kehidupan sehari-hari yang mempermudah siswa sebelum memahami definisi dari relasi dan fungsi itu sendiri. Ilustasi dalam modul ini digunakan untuk membantu siswa memahami materi yang sedang dipelajari. Hal itu sesuai dengan pendapat Gilang, Sihombing, \& Sari (2017) bahwa ilustrasi membantu memberikan penjelasan mengenai materi yang sedang dibahas dan membantu siswa untuk memahami pesan yang disampaikan dengan mudah. Ilustrasi dalam modul ini memuat gambar serta isian yang harus diisi siswa sehingga siswa dapat terbiasa membuat suatu model masalah berupa tulisan dari permasalahan yang diberikan.Contoh ilustrasi yang digunakan dalam modul ini termuat dalam Gambar 1.

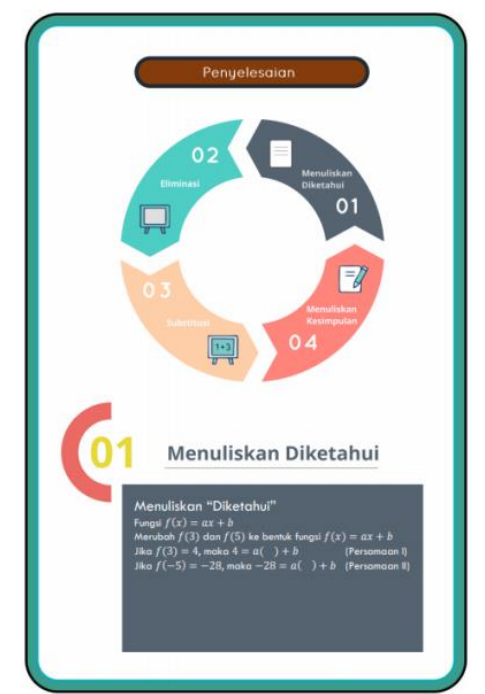

Gambar 2. Substitusi dan Eliminasi 
Pada materi fungsi, terdapat suatu contoh soal tentang penentuan suatu fungsi dengan menggunakan cara eliminasi dan substitusi. Pada contoh soal tersebut, terdapat cara penyelesaian atau strategi dalam menyelesaikan soal tersebut. Terdapat gambar urutan dalam penyelesaian yang didesain dengan menarik serta langkah-langkahnya seperti yang termuat dalam Gambar 2. Dengan cara tersebut, siswa dapat mengerti strategi penyelesaian soal fungsi dengan menggunakan teknik eliminasi dan substitusi serta persamaan aljabar di dalamnya.

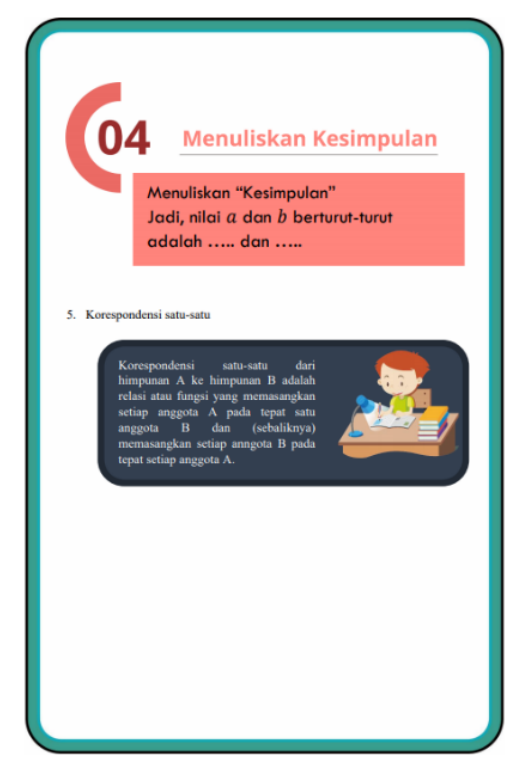

Gambar 3. Kesimpulan

Pada langkah terakhir dalam penyelesaian soal fungsi menggunakan eliminasi dan substitusi, terdapat suatu penyimpulan masalah berupa "Menuliskan Kesimpulan" (Gambar 3). Langkah tersebut dapat melatih siswa agar terbiasa dalam menuliskan kesimpulan menggunakan bahasanya sendiri berupa tulisan dari hasil penyelesaian masalah yang telah dikerjakannya. Menurut Rodiah \& Triyana (2019) dalam membuat kesimpulan diperlukan penalaran deduktif, alasan-alasan yang masuk akal, dan perlu menguji kevalidan dari argumen yang digunakan. Untuk itu, penarikan kesimpulan dalam modul ini dilakukan dilangkah terakhir agar siswa mampu membuat penarikan kesimpulan berdasarkan strategi penyelesaian yang telah dilakukan sebelumnya.

Pada tahap development juga dilakukan validasi modul, lembar soal tes, dan lembar angket respon siswa dimana persentase yang didapat olehmasingmasing uji kevalidan sebesar 89\%, 85\%, dan 91\%. Menurut Arikunto (2010) hasil validasi tersebut termasuk dalam interpretasi sangat valid sehingga instrumen penelitian bisa digunakan untuk penelitian. 


\section{Implementation}

Modul yang sudah dinyatakan valid diuji cobakan kepada 23 siswa kelas VIII di salah satu SMP Negeri Kota Batu yang sudah menempuh materi relasi dan fungsi untuk mengetahui peningkatan kemampuan komunikasi matematis siswa pada materi tersebut. Sebelum modul diuji cobakan, siswa diminta mengerjakan soal pretestuntuk mengetahui kemampuan awal komunikasi matematis tertulisnya. Setelah uji coba modul, siswa diminta mengerjakan soal posttest untuk mengetahui peningkatan kemampuan komunikasi matematis tertulis siswa pada materi relasi dan fungsi.

Hasil tes selanjutnya dianalisis menggunakan uji normalitas data untuk mengetahui kenormalan dari data yang didapat. Uji normalitas dilakukan dengan menggunakan software SPSS. Uji normalitas yang digunakan adalah teknik shapiro-wilk. Teknik shapiro-wilk digunakan untuk sampel yang jumlahnya kecil dengan jumlah kurang dari 50 data. Data dikatakan berdistribusi normal jika nilai sig dari shapiro-wilk $\geq 0.05$. Jika nilai sig dari shapiro-wilk $<0.05$ maka data tersebut tidak berdistribusi normal. Berikut hasil output uji normalitas dari shapiro-wilk menggunakan SPSS.

\begin{tabular}{ll|l|l|l|r|r|r} 
& \multicolumn{4}{c}{ Kolmogorov-Smirnov $^{\text {a }}$} & \multicolumn{3}{c}{ Shapiro-Wilk } \\
\hline \multirow{2}{*}{ Nilai } & Tes & Statistic & \multicolumn{1}{c}{ df } & \multicolumn{1}{c|}{ Sig. } & Statistic & \multicolumn{1}{c}{ df } & \multicolumn{1}{c}{ Sig. } \\
\cline { 2 - 9 } & Pretest & .342 & 23 & .000 & .769 & 23 & .000 \\
\hline & Posttest & .119 & 23 & $.200^{\star}$ & .957 & 23 & .407 \\
\hline
\end{tabular}

Gambar 4. Uji Normalitas Hasil Pretest dan Posttest Siswa

Berdasarkan gambar 4, didapat nilai sig dari shapiro-wilk pada baris pretest sebesar 0.000, sedangkan nilai sig dari shapiro-wilk pada baris posttest sebesar 0.407. Pada baris pretest nilai sig yang didapat kurang dari 0.05 maka dapat disimpulkan data berdistribusi tidak normal. Dikarenakan data berdistribusi tidak normal, maka langkah selanjutnya pengujian menggunakan uji Wilcoxon. Uji Wilcoxon dilakukan untuk mengetahui peningkatan kemampuan komunikasi matematis tertulis siswa dari hasil pretest dan posttest.

\begin{tabular}{|c|c|c|c|c|}
\hline \multicolumn{5}{|c|}{ Ranks } \\
\hline & & $N$ & Mean Rank & $\begin{array}{l}\text { Sum of } \\
\text { Ranks }\end{array}$ \\
\hline \multirow[t]{4}{*}{ Posttest-Pretest } & Negative Ranks & $0^{a}$ & .00 & .00 \\
\hline & Positive Ranks & $23^{\mathrm{b}}$ & 12.00 & 276.00 \\
\hline & Ties & $0^{c}$ & & \\
\hline & Total & 23 & & \\
\hline \multicolumn{5}{|c|}{ a. Posttest < Pretest } \\
\hline \multicolumn{5}{|c|}{ b. Posttest > Pretest } \\
\hline \multicolumn{5}{|c|}{ c. Posttest $=$ Pretest } \\
\hline
\end{tabular}

Gambar 5. Output Ranks dari Uji WilcoxonHasil Pretest dan Posttest Siswa 
Selanjutnya dilakukan pengambilan keputusan dari hasil output yang didapat dari SPSS. Gambar 5 menunjukkan Output pada tabel Ranks, terdapat Negative Ranks dengan nilai 0 yang menunjukkan tidak adanya penurunan dari nilai pretest ke nilai posttes. Pada baris Positive Ranks didapat nilai 23 yang berarti terdapat 23 data positif dan 23 siswa tersebut mengalami peningkatan kemampuan komunikasi matematis tertulis dari nilai pretest dan posttest. Pada kolom Mean Rank, peningkatan tersebut sebesar 12, sedangkan jumlah ranking positif atau Sum of Ranks sebesar 276. Pada baris Ties didapat nilai sebesar 0 yang menunjukkan tidak adanya nilai yang sama antara nilai pretest dan nilai posttest.

Tabel 4. Test Statistics

\begin{tabular}{ll}
\hline & Posttest-Pretest \\
\hline Asymp. Sig. (2-tailed) & 0.000 \\
\hline
\end{tabular}

Selanjutnya dilakukan pengambilan keputusan dan kesimpulan dari tabel4. Dasar pengambilan keputusan menggunakan uji Wilcoxondengan melihat nilai Asymp. Sig. (2-tailed). Jika nilai Asymp. Sig. (2-tailed) kurang dari 0.05, maka $\mathrm{H}_{0}$ ditolak dan $\mathrm{H}_{1}$ diterima. Sedangkan jika nilai Asymp. Sig. (2-tailed) lebih dari 0.05, maka $\mathrm{H}_{0}$ diterima dan $\mathrm{H}_{1}$ ditolak. Berdasarkan output dari tabel Test Statistics, didapat nilai Asymp. Sig. (2-tailed) sebesar 0.000. Dikarenakan nilai Asymp. Sig. (2-tailed) kurang dari 0.05, maka $\mathrm{H}_{0}$ ditolak dan $\mathrm{H}_{1}$ diterima yang berarti "Ada peningkatan kemampuan komunikasi matematis tertulis siswa sebelum dan sesudah menggunakan bahan ajar modul".

Tabel 5. Nilai Pretest, Posttest, dan N-Gain

\begin{tabular}{|c|c|c|c|c|c|}
\hline \multicolumn{2}{|c|}{ Pretest } & \multicolumn{2}{|c|}{ Posttest } & \multirow{2}{*}{ N-Gain } & \multirow{2}{*}{ Interpretas } \\
\hline Jumlah & Rata-rata & Jumlah & Rata-rata & & \\
\hline 317 & 13,78 & 1495 & 65 & 0,59 & Sedang \\
\hline
\end{tabular}

Setelah diketahui terdapat peningkatan kemampuan komunikasi matematis tertulis siswa, selanjutnya akan diketahui interpretasi dari peningkatan yang didapat menggunakan perhitungan N-Gain. Berdasarkan tabel 5, didapat nilai $N$-Gain sebesar 0,59 dengan interpretasi peningkatan kemampuan komunikasi matematis tertulis siswa adalah "Sedang".Artinya, kemampuan komunikasi matematis tertulis siswa meningkat setelah diberikan modul untuk pembelajaran materi relasi dan fungsi. Hal ini sejalan dengan Mardiah (2018)yang menyatakan bahwa mengembangkan bahan ajar berupa modul matematika dapat membuat siswa lebih tertarik dan lebih aktif saat belajar.

Hasil penelitian Pornamasari (2017) juga menyebutkan bahwa kemampuan belajar siswa pada materi relasi dan fungsi dengan menggunakan modul 
pembelajaran berbantuan Flipbook maker dengan model NHT berbasis teori Vygotsky lebih baik dari pada prestasi belajar siswa yang menggunakan modul tanpa ilustrasi. Hasil tersebut sesuai dengan hasil dari penelitian ini. Siswa lebih tertarik untuk belajar karena terdapat ilustrasi yang membantu siswa untuk memahami materi relasi dan fungsi dengan jelas. Akibatnya, hasil belajar siswa juga mengalami peningkatan. Hal itu dikarenakan pemanfaatan konteks yang tepat serta keaktifan siswa dan guru dalam pembelajaran dapat membantu dalam menumbuhkan dan membangun pemahaman relasional siswa (Hanifah, Noornia, \& Sampoerno, 2019).

\section{Evaluation}

Pada tahapan evaluasi dilakukan uji kepraktisan dari modul yang telah dikembangkan. Uji kepraktisan modul digunakan untuk mengetahui apakah modul yang telah dikembangkan sudah bisa mempermudah siswa dalam belajar dan memiliki respon yang positif terhadap modul tersebut.

Hasil persentase yang diperoleh dari uji praktisi yang dilakukan kepada 23 siswa diperoleh rata-rata sebesar 80\%yang menunjukkan respon positif. Menurut skala Ghuttman, modul tersebut praktis untuk digunakan karena memiliki persentase $>70 \%$ (Kiswanto \& Amin, 2012). Hasil tersebut sesuai dengan penelitian yang dilakukan Nadzia (2018)mengenai pengembangan modul. Uji kepraktisan yang dihasilkan mempunyai respon positif sebesar $79,60 \%$ sehingga modul yang dikembangkan layak diterapkan dalam pembelajaran matematika. Merujuk pada uraian tersebut, modul bisa dikatakan praktis untuk digunakan dalam mempelajari materi relasi dan fungsi. Hasil angket juga menyatakan bahwa beberapa siswa mengalami sedikit kendala saat membaca dan memahami isi modul. Dengan demikian pada pelaksanaan dan uji coba modul, peneliti sebagai fasilitator membantu siswa saat uji coba modul berlangsung. Siswa diberikan kesempatan untuk bertanya apabila terdapat kesulitan saat membaca dan memahami isi modul dan peneliti membantu siswa yang mengalami kesulitan.

Merujuk pada uraian tersebut, terlihat bahwa siswa terbantu dengan adanya modul pembelajaran. Hasil tersebut serupa dengan penelitian terdahulu yang menyatakan bahwa pembelajaran dengan menggunakan modul memiliki dampak yang signifikan terhadap peningkatan keterampilan komunikasi matematis siswa dalam menyelesaikan persoalan yang diberikan guru, peningkatan hasil hasil belajar, dan prestasi siswa (Hima, 2017; Kusuma, 2017; Mardiah, 2018; Pornamasari, 2017). Sehingga dalam hal ini, guru harus mampu membuat modul yang dapat meningkatkan kemampuan komunikasi 
tertulis siswa. Modul tersebut dapat digunakan sebagai bahan ajar tambahan ketika melakukan proses belajar mengajar.

\section{Simpulan}

Bahan ajar modul pada materi relasi dan fungsi dikembangkan untuk meningkatkan kemampuan komunikasi matematis tertulis siswa. Prosedur penelitian dalam pengembangan modul mengacu pada model pengembangan ADDIE. Uji validasi dilakukan oleh dosen pendidikan matematika dan guru matematika SMP. Diperoleh hasil uji validasi modul yang menyatakan bahwa modul valid dan layak untuk digunakan.

Hasil uji coba keefektifan modul dari soal pretest dan posttest menggunakan SPSS dengan menguji kenormalan data menggunakan shapiro-wilk didapat bahwa ada peningkatan kemampuan komunikasi matematis tertulis siwa sebelum dan sesudah menggunakan bahan ajar modul dengan interpretasi peningkatannya adalah "Sedang". Dengan demikian dapat disimpulkan bahwa modul dikatakan efektif. Hasil uji coba kepraktisan modul juga menyatakan bahwa modul praktis untuk digunakan. Sehingga dalam hal ini guru dapat menggunakan modul ini sebagai bahan ajar tambahan dalam mengajar materi relasi dan fungsi untuk siswa SMP.

Temuan dan hasil pengembangan modul dalam penelitian ini dapat digunakan sebagai acuan oleh peneliti selanjutnya dalam mengembangkan modul materi relasi dan fungsi yang lainnya. Selain itu, peneliti selanjutnya juga bisa melakukan analisis kesalahan dan miskonsepsi yang mungkin terdapat dalam modul ini.

\section{Daftar Pustaka}

Agustyarini, Y., \& Jailani. (2015). Pengembangan Bahan Ajar Matematika Dengan Pendekatan Kontekstual Dan Metode Penemuan Terbimbing Untuk Meningkatkan EQ Dan SQ Siswa SMP Akselerasi. Jurnal Riset Pendidikan Matematika, 2(1), 135-147. https://doi.org/10.21831/jrpm.v2i1.7156

Arikunto. (2010). Prosedur Penelitian: Suatu Pendekatan Praktik. Rineka Cipta.

Asmana, A. T. (2018). Profil Komunikasi Matematika Tertulis dalam Pemecahan Masalah Matematika di SMP ditinjau dari Kemampuan Matematika. Jurnal Inovasi Pendidikan Dan Pembelajaran Matematika, 4(1), 1-12.

Dick, W., Carey, L., \& Carey, J. O. (1978). The Systematic Design of Instruction. Scott, Foresman and Company.

Gilang, L., Sihombing, R. M., \& Sari, N. (2017). Kesesuaian Konteks dan Ilustrasi pada Buku Bergambar untuk Mendidik Karakter Anak Usia Dini. Jurnal Pendidikan Karakter, 7(2), 158-169. https://doi.org/10.21831/jpk.v7i2.15799

Hake, R. R. (1999). Analyzing Change/Gain Scores. Unpublished.[Online] URL: Http://Www. Physics. Indiana. Edu/ $\sim$ Sdi/AnalyzingChange-Gain. Pdf.

Hanifah, R., Noornia, A., \& Sampoerno, P. D. (2019). Pengembangan Pembelajaran dalam 
Membangun Pemahaman Relasional Siswa Melalui Pendekatan PMRI Materi Relasi dan Fungsi. Prima: Jurnal Pendidikan Matematika, 3(2), 103-115. https://doi.org/10.31000/prima.v3i2.950

Herawati, A. S. (2014). Kontruksi Konsep Relasi Dan Fungsi Dalam Sistem GUI MATLAB. Prosiding Seminar Nasional Matematika, 268-271.

Hima, L. R. (2017). Pengembangan Modul Pembelajaran dengan Strategi Peningkatan Kemampuan Berpikir untuk Meningkatkan Kemampuan Komunikasi Matematis Siswa. Ed-Humanistics, 2(2), 232-239.

Kaya, D., \& Aydin, H. (2016). Elementary Mathematics Teachers' Perceptions and Lived Experiences on Mathematical Communication. Eurasia Journal of Mathematics, Science and Technology Education, 12(6), 1619-1629. https://doi.org/10.12973/eurasia.2014.1203a

Kiswanto, H., \& Siti Maghfirotun Amin. (2012). Pengembangan Media Pembelajaran Interaktif Berbantuan Komputer Pada Materi Dimensi Tiga. MATHEdunesa, 1(1), 21-29.

Kusuma, A. C. (2017). Efektifitas Pembelajaran Tutor Sebaya Berbantuan Modul Untuk Meningkatkan Komunikasi Matematik Mahasiswa. Cakrawala: Jurnal Pendidikan, 11(2), 1-8. https://doi.org/10.24905/cakrawala.v11i1.649

Lanani, K. (2013). Belajar Berkomunikasi Dan Komunikasi Untuk Belajar Dalam Pembelajaran Matematika. Jurnal Ilmiah Program Studi Matematika STKIP Siliwangi Bandung, 2(1), 1325. https://doi.org/10.22460/infinity.v2i1.21

Lestari, W., \& Handayani, S. (2018). Pengembangan Modul Matematika Berbasis Matematika Realistik Untuk Kelas VII SMP Semester I. Jurnal Analisa, 4(1), 51-60. https://doi.org/10.1051/matecconf/201712107005

Lutvaidah, U. (2016). Pengaruh Metode dan Pendekatan Pembelajaran terhadap Penguasaan Konsep Matematika. Formatif: Jurnal Ilmiah Pendidikan MIPA, 5(3), 279-285. https://doi.org/10.30998/formatif.v5i3.653

Mardiah, S. (2018). Pengembangan Modul Pembelajaran Matematika Berbasis Etnomatematika Menggunakan Metode Inkuiri Pada Kelas VII. In Skripsi: Tidak Diterbitkan. https://doi.org/10.1093/imamci/dnt037

Mawaddah, S., \& Anisah, H. (2015). Kemampuan Pemecahan Masalah Matematis Siswa Pada Pembelajaran Matematika dengan Menggunakag) di SMPN Model Pembelajaran Generatif (Generative Learning) di SMP. EDU-MAT: Jurnal Pendidikan Matematika, 3(2), 15-30. https://doi.org/10.20527/edumat.v3i2.644

Mawaddah, S., \& Maryanti, R. (2016). Kemampuan Pemahaman Konsep Matematis Siswa SMP dalam Pembelajaran Menggunakan Model Penemuan Terbimbing (Discovery Learning). EDU-MAT: Jurnal Pendidikan Matematika, 4(1), 76-85. https://doi.org/10.20527/edumat.v4i1.2292

Nadzia, E. (2018). Pengembangan Modul Elektronik Pada Pokok Bahasan Relasi dan Fungsi Kelas X SMK. Skripsi : Tidak Diterbitkan.

Parrot, M. A. S., \& Leong, K. E. (2018). Impact of Using Graphing Calculator in Problem Solving. International Electronic Journal of Mathematics Education, 13(3), 139-148.

Pornamasari, E. I. (2017). Pengembangan Modul Pembelajaran Berbantu Flipbook Maker Dengan Model Pembelajaran Numbered Heads Together (NHT) Berbasis Teori Vygotsky Materi Pokok Relasi Dan Fungsi. Aksioma: Jurnal Matematika Dan Pendidikan Matematika, 7(1), 74-83. https://doi.org/10.26877/aks.v7i1.1412

Puspa, S., Riyadi, R., \& Subanti, S. (2019). Profile of Mathematical Communication Skills Junior High School Students in Problem Solving. Journal of Physics: Conference Series, 1157(3), 06. https://doi.org/10.1088/1742-6596/1157/3/032125

Ramdani, R., Syamsuddin, A., \& Sirajuddin, S. (2019). Development of Mathematical ModuleProblem Solving Approach to Train Student's Reflective Thinking. Pedagogical Research, 4(4). https://doi.org/10.29333/pr/5861 
Ramdani, Y. (2012). Pengembangan Instrumen dan Bahan Ajar untuk Meningkatkan Kemampuan Komunikasi, Penalaran, dan Koneksi Matematis dalam Konsep Integral. Jurnal Penelitian Pendidikan, 13(1), 44-52.

Rizkianto, I., \& Santosa, R. H. (2017). The Anaysis Of Junior High School Students Mathematics Book 2013 Curriculum. Mosharafa, 6(2), 229-236.

Rodiah, S., \& Triyana, V. A. (2019). Analisis Kemampuan Penalaran Matematis Siswa Kelas IX MTS Pada Materi Sistem Persamaan Linear Dua Variabel Berdasarkan Gender. Jurnal Kajian Pembelajaran Matematika, 3(1), 1-8.

Rohid, N., Suryaman, \& Rusmawati, R. D. (2019). Students' Mathematical Communication Skills (MCS) in Solving Mathematics Problems: A Case in Indonesian Context. Anatolian Journal of Education, 4(2), 19-30. https://doi.org/10.29333/aje.2019.423a

Saddadi, M. I. (2019). Pengembangan Media Pembelajaran Berbasis Flash Pada Materi Operasi Bilangan Bulat Untuk Meningkatkan Pemahaman Konsep Siswa SMP. In Skripsi : Tidak Diterbitkan. Universitas Muhammadiyah Malang.

Suhartati. (2016). Penerapan Pendekatan Saintifik Pada Materi Relasi Dan Fungsi Di Kelas X MAN 3 Banda Aceh. Jurnal Peluang, 4(2), 56-65.

Wahyuni, S., Yati, M., \& Fadila, A. (2020). Pengembangan Modul Matematika Berbasis REACT terhadap Kemampuan Komunikasi Matematis Peserta Didik. Jambura Journal of Mathematics Education, 1(1), 1-12. https://doi.org/10.34312/jmathedu.v1i1.4542

Yanti, R. N., Melati, A. S., \& Zanty, L. S. (2019). Analisis Kemampuan Pemahaman dan Kemampuan Komunikasi Matematis Siswa SMP pada Materi Relasi dan Fungsi. Jurnal Cendekia: Jurnal Pendidikan Matematika, 3(1), 209-219. https://doi.org/10.31004/cendekia.v3i1.95 